\title{
Daughters and Sons of Solidarity Ask Questions: Resistance, Gender, Race, and Class in Transgenerational Women's Auto/ biography, Film and New Media ${ }^{1}$
}

\begin{abstract}
Daughters and Sons of Solidarity Ask Questions: Resistance, Gender, Race, and Class in Transgenerational Women's Auto/biography, Film and New Media. Unlike American historians challenging marginalization of women since the 1970s and theorizing usefulness of gender for history, the majority of Polish historians have been rather reluctant to address gender differences. The collapse of communism and transatlantic interest in retraditionalization stimulated interdisciplinary engendering of Solidarity. This article examines how significant, despite being strategically invisible, Solidarity women activists of the 1980s have been represented in oral history, auto/ biography, film and new media as well as in dialogical genres such as auto/biography and relational memoir. The questioning of mythical visions of Solidarity focused on men and class has initially been resisted, but encouraged a debate about gender stereotypes in Poland. The early "archive fever" followed by a recent surge in transgenerational life writing on women oppositionists exploring gender along with ethnicity, class and age has helped to construct multi-layered portraits of anti-communist resistance. In the award-winning documentary and extended interviews, several Solidarity women activists evaluate critically their occasional complicity with (post)totalitarian system, which may complicate ultranationalist narratives and fill a number of gaps in postcolonial and post-totalitarian studies of Central and Eastern Europe.
\end{abstract}

Keywords: gender, Solidarity, race, film, new media

* Address: Institute of English Studies IFA, ul. Kuźnicza 22, 50-138 Wrocław. E-mail: elzbieta. klimek-dominiak@uwr.edu.pl

1 The first part of this article was published in Miscellanea Posttotalitariana Wratislaviensia Special Issue, vol. 1 (5)/2016, as "Resisting (in)visible women of Solidarity: Gender in American and Polish oral history, life writing, visual arts and film. Part I”, pp. 103-121. 
Дочери и сыны солидарности задают вопросы: сопротивление, пол, раса и класс в межгенерационной авто/биографии женщин, кино и новых медиа. В отличие от американских историков, бросающих с 1970-х годов вызов маргинализации женщин и теоретизирующих полезность пола для истории, большинство польских историков довольно неохотно занимались гендерными различиями. Крах коммунизма и трансатлантический интерес к возрождению традиций стимулировал междисциплинарное создание »Солидарности«. В этой статье рассматривается как женщины-активисты „Солидарности« 1980-х годов, которые делали все возможное, чтобы стать стратегически невидимыми, были показаны в устной истории, в автобиографии и кино, новых медиа а также в таких диалогических жанрах, как автобиография и мемуары. Опрос, касающийся мифического изображения »Солидарности«, сосредоточен на мужчинах и классах, был отвергнут, но побудил дискуссию о гендерных стереотипах в Польше. Ранняя »архивная лихорадка«, за которой последовал недавний всплеск трансцендентной жизни, в рамках которой писалось о женщинах-оппозиционерах, изучающих гендерные аспекты, а также этническую принадлежность, класс и возраст, помогла построить многослойные портреты антикоммунистического сопротивления. Анализ успешного документального фильма, который был подвергнут критике со стороны женщин »Солидарности« за их соучастие в (пост)тоталитарной системе, может также усложнить ультранационалистические рассказы и заполнить ряд разрывов в постколониальных исследованиях Центральной Европы.

Ключевые слова: гендер, „Солидарность«, раса, кино, новые медиа

\section{Backlash — Resisting Solidarity women's public visibility in the post-communist context}

Surprisingly, Polish reception of Penn's seminal transnational study, Podziemie Kobiet [Women's Underground], was mixed even among a few of the interviewed Solidarity activists of the 1980s, as Penn's feminist standpoint and her gendered research questions may have been associated with the communist regime's propaganda appropriation of equal rights' discourse and their fear of being co-opted as the allies of a post-communist party ${ }^{2}$. As a result, Penn's second study summarizing her over a decade-long collaborative research, Solidarity's Secret: Women Who Defeated Communism in Poland, included not only her exploration of the oral history about women's resistance, but also the analysis of the language used in Polish public discussions during the conservative anti-feminist revolution in her chapter "Filling in the Blank Spot: The Public Discourse on Women." It was also accompanied by the "Appendix" containing the long excerpts from an important Polish debate about the Solidarity women interviewed by Penn and the ambivalent attitudes towards feminism and gender history which some of them expressed about their public visibility.

2 See e.g. M. Tarasiewicz, [in:] J. Feffer, “Buiding the woman's movement”, Huffington Post. The World Post 10.04.2015, http://www.huffingtonpost.com/john-feffer/building-the-womens-movem_b_7039784.html- (access: 26.08.2016). See also an interview with the major resistance women activist, Ewa Kulik, [in:] J. Feffer, "Solidarity underground", Huffington Post. The World Post 4.07.2015, http:// www.huffingtonpost.com/john-feffer/solidarity-underground_b_7019818.html- (access: 5.07.2015).

Miscellanea Posttotalitariana Wratislaviensia 6/2017

(C) for this edition by CNS 
This long and intense debate consisting of 13 polemical texts published during three months was initiated by a younger scholar, Agnieszka Graff, and her article "Patriarchat po Seksmisji" [Patriarchy after Sexmission] problematizing the relatively insignificant response of the Polish mainstream media to Penn's initial findings and ascribing it to the deeply ingrained gender discrimination in post- 1989 Poland. Significantly, Graff invoked the experience of her own transatlantic education in gender studies to support Penn's outsider perspective ${ }^{3}$. Many Solidarity women dissidents and public intellectuals who took part in this extended discussion and contributed their texts, which were published in Gazeta Wyborcza in $1999^{4}$ are included in Penn's Appendix.

Paradoxically, one of the Solidarity women editors of Tygodnik Mazowsze, who was quoted with permission in Penn's studies and discussed in Graff's texts, Joanna Szczęsna, resisted Graff's feminist interpretation and her public visibility in the discussion about gender discrimination in Polish underground because for her feminism was "a needless luxury in those days" . In her response, Maria Janion, one of the accomplished Polish women scholars, supported Graff's position by explaining to Szczęsna that "individual choices do not change the greater dynamic that Graff described. Solidarity turned away from women making them understand clearly that they are not welcome in places where there are no longer national fires to put out, but where there is money, privilege and power" ${ }^{\prime \prime}$ and emphasizing the importance of transgenerational connections between women suggested the need for "the philosophy of difference" and refusing to pretend that "gender does not matter"7. In conclusion, Zuzanna Siemieńczuk asserted that "In a dangerously convincing way, Podziemie Kobiet changes our familiar, historical perspective..." and recognized American scholar's pioneering contribution: "Thanks to Shana Penn, Solidarity women have finally come out of hiding" ${ }^{8}$. Importantly, the Polish edition of the study, which also includes this rare mainstream media debate about the in/visibility of the underground Solidarity women, Sekret Solidarności [Solidarity's Secret] (2014), published by the major Polish publishing house, WAB, coincided with the opening of Europejskie Centrum Solidarności [European Solidarity Center] (ECS)

3 A. Graff, "Patriarchy after Sexmission" [after:] S. Penn, Solidarity's Secret. The Women Who Defeated Communism in Poland, Ann Arbor 2005, p. 328 containing an abridged version of her 1999 article "Patriarchat po Seksmisji" [Patriarchy after Sexmission], Gazeta Wyborcza (Warsaw edition), June 19-20, 1999. Świąteczna [Weekend section], pp. 20-23.

4 S. Penn, "Appendix" [in:] eadem, op. cit., pp. 325-339.

5 J. Szczęsna, "Ladies, Knights, and Fireperson", Gazeta Wyborcza, June 27 1999, pp. 22-23. Also [in:] S. Penn, Solidarity's Secret: Women Who Defeated Communism in Poland, New York 2005, p. 332; and eadem, [Sekret Solidarności] transl. M. Antosiewicz, Warszawa 2015, p. 389.

6 M. Janion, "For Your Freedom and Ours", (Gazeta Wyborcza July 4, 1999, p. 20.) [after:] S. Penn, op. cit., p. 333.

7 Ibid., p. 334.

8 S. Penn, op. cit., pp. 338-339. 
in Gdańsk and in this way provided a broader perspective in addition to a rather scant representation of Solidarity women in ECS's permanent exhibition ${ }^{9}$.

\section{Comparative, intersectional oral history of Polish women's resistance}

In her recent research, Penn has pursued comparative oral history studies of resistance activists of the 1970s and 1980s in the Central and Eastern Europe representing various ethnic, social backgrounds and different ages by discussing the impact of Jewish identity and post-WWII dislocations on two Polish feminist resistance activists in "Writing Themselves into History: Two Feminists Recall Their Political Development in the People's Republic of Poland" $(2009)^{10}$. Penn also takes part in conferences exploring intersections of gender, ethnicity and age in Polish as well as the Central and Eastern European women dissidents' oral narratives. ${ }^{11}$ Thus Penn's transcultural publications and her frequent contacts with the Polish academics and activists have continued to exert a significant impact by stimulating a transnational debate about gender in Poland and by dialogizing the dominant narrative of the bearded, self-reliant Polish freedom fighters with images of previously anonymous women resistance activists of various ethnic, class backgrounds and age. Her publications have also inspired intercontinental gender history research on women's active involvement in the anti-communist resistance and have constituted an important attempt to complicate the way gender of the underground has been discussed both in Poland and abroad.

A further instance of the significant impact, which the transnational oral history "archive fever" about women's resistance exerted on Polish oral history, is the collection of personal narratives, Feministki własnym głosem o sobie [Feminists in Their Own Voices] (2005), edited by the accomplished philosopher and publisher, Sławomira Walczewska. In this volume, several Polish feminist writers, scholars and activists of different generations, ethnic and social backgrounds, discuss their formative experiences in the resistance movements in the 1970s and 1980s. For example, in her oral history "Solidarność kobiet” [Women’s Solidarity] Małgorzata Tarasiewicz docu-

9 Europejskie Centrum Solidarności (eds.), Permanent Exhibition. An Anthology, Gdańsk 2015.

10 S. Penn, "Analiza porównawcza działalności kobiet w czechosłowackich i polskich ruchach opozycji antykomunistycznej w latach 1968-1989" [A Comparative Look at Women in Czechosloak and Polish Anti-Communist Opposition Movements, 1968-1989], [in:] N. Jarska, J. Olaszek (eds.), Płeć Buntu. Kobiety w Oporze Społecznym i opozycji w Polsce w latach 1944-1989 na tle porównawczym, Warszawa 2014, pp. 355-369; S. Penn, "Writing Themselves into History: Two Feminists Recall Their Political Development in the People's Republic of Poland", [in:] S. Penn, J. Massino (eds.), Gender Politics and Everyday Life in State Socialist Eastern and Central Europe, New York 2009, pp. 201-219.

11 For example: "Kobiety i Solidarność. Skąd przychodzimy, dokąd zmierzamy?" [Women and Solidarity. Where have we come from, where are we going?"], Heinrich Böll Stiftung, Warszawa, June 2 2014, https://pl.boell.org/pl/2014/05/28/kobiety-i-solidarnosc-skad-przychodzimy-dokad-zmierzamy(access: 11.05.2015). 
ments the notorious case of gender discrimination within Solidarity, which she experienced as the coordinator of Solidarity's Women Section ${ }^{12}$ because she supported women's self-representation in the trade union's leadership and women's reproductive rights disapproved by the Solidarity leader in 1991. As a result, this women's section was abolished by the Solidarity's male principal, Marian Krzaklewski, but the gender discrimination case was investigated and reported in Human Rights Watch ${ }^{13}$. Tarasiewicz also outlines her later involvement in the feminist NGO, the Network of East-West Women first in New York and later also in the locally-situated regional chapter NEWW-Poland, this way depicting one of the popular occupation choices by former underground women activists.

In "Dziewczyna opozycjonisty" [Oppositionist's Girlfriend], Agnieszka Graff analyzes how conservative Polish gender contract regulated relationships between freedom fighters in the resistance movement. She also portrays her creative use of the strategy of tactical frivolity, which she experienced first in the opposition movement of the late 1980s, in her post-1989 feminist resistance activism such as Manifa demonstrations. In her "Ucieczka do wolności" [Escape to Freedom] Barbara Limanowska reflects on the impact of student strikes of the 1980s, her emigration and her later leadership in many women's rights organizations such as La Strada. Finally, in one of the most poignant life narratives, "Stemplowanie tożsamości" [Identity Stamping], Bożena Umińska, self-identifying as a Jewish feminist, describes her tremendous shock during the Polish March in 1968 student and intellectual protests, which were followed by the brutal government-led anti-Semitic campaign and purges.

This publication is not only valuable as a polyphonic, locally-situated collection of underground resistance narratives, but also as an example of a successful, transnational collaboration with the University of Michigan's "Global Feminisms" oral history project. Significantly, these interviews were conducted by the Polish interviewer/editor and co-director of Polish woman's foundation, eFKa, Sławomira Walczewska ${ }^{14}$.

12 See the more detailed account of this [in:] M. Tarasiewicz, "Kobiety i Związek Zawodowy 'Solidarność”, Pełnym Głosem Summer 1993, no. 1Z, pp. 30-33. Also in S. Penn, 2003. Podziemie Kobiet, 2005. Solidarity's Secret.

${ }^{13}$ M. Tarasiewicz, "Solidarność kobiet” [Women’s Solidarity], [in:] S. Walczewska (eds.), Feministki własnym głosem o sobie [Feminists in Their Own Voices], Kraków 2005, pp. 21-33, here: p. 30.

14 A. Graff, "Dziewczyna opozycjonisty", pp. 80-108, Barbara Limanowska "Ucieczka do wolności" [Escape to Freedom], pp. 109-120, Bożena Umińska "Stemplowanie tożsamości” [Identity Stamping], pp. 109-120 [in:] Feministki własnym głosem o sobie. "Global Feminisms" project was coordinated by Abigail Stewart. Ibid., pp. 19-20. See also interviews with the major women activist of the underground Solidarity, E. Kulik, [in:] J. Feffer, op. cit. and about M. Tarasiewicz, [in:] J. Feffer, op. cit. 


\section{Solidarity's daughters and sons ask questions — transgenerational life writing}

Although gender has not been a prominent analytical category among the mainstream, professionally trained Polish historians, after the collapse of communism the transatlantic research on pro-democratic opposition, transformation and retraditionalization in Poland after $1989^{15}$ as well as transnational feminists' and gender studies scholars' recognition of the need for women's and gender history ${ }^{16}$ provided influential stimuli to the early attempts at engendering of the recent Polish history. This first influential stage of American and Polish interdisciplinary oral history projects and collected life narratives was initiated with Penn's research and oral interviews with Solidarity women in 1991 and continued among others by Kondratowicz's two expansive oral history projects, Feffer's oral interviews and oral testimonies of several feminist women oppositionists conducted by Walczewska and published as a part of transnational project "Global Feminisms" in 2005. They popularized the oral history methodology especially among the Polish gender studies scholars and scholars/activists from non-governmental organizations and feminist foundations. They also stimulated growth of archive material in the form of many life writing genres such as voice recordings of transitory memories, official documents of arrest and search warrants, court ruling written in the communist "newspeak", to use Orwell's popular term, oppositionists' satirical songs about the communist repressions as well as film and photographic evidence of underground editing, printing, education, politics and other forms of underground activism. These hybrid oral history narratives collected soon after the victory of underground "patient revolution" of 1989 and published between 1994-2005 have recently been followed by a new surge in more extended, often book-length or multimedia interviews, film and artwork frequently authored by a younger generation of both female and male, writers, artists and activists.

Importantly, the twentieth anniversary of the first partially free elections in Poland and the Soviet block, commemorated in 2009 for example by the National Museum exhibition devoted primarily to Solidarity men and many other official celebrations, with no significant representation of women, became a turning point for many Polish women. The same year, numerous women academics, businesswomen and other women activists decided a new social movement was needed to prevent further erasure of underground Solidarity women from public memory and to collectively discuss strategies ensuring women's greater visibility and agency in the Polish public

15 About conservative revolution and the pressure on the return to traditional gender roles see for example P. Watson, “Eastern Europe’s Silent Revolution: Gender”, Sociology 1993, no. 3, 27, pp. 471-487.

16 For example S. Walczewska, "O potrzebie historii kobiecej” [The Need for Women's History], [in:] S. Walczewska (ed.), Głos mają kobiety. Teksty feministyczne [In Their Own Voice, Feminist Texts], Kraków 1992, pp. 57-63. 
life. The initiative was called Kongres Kobiet [the Congress of Women] and the first edition, focused on "20 Years of Transformation: 1989-2009", gathered four thousand women. Significantly, during this large meeting Henryka Krzywonos-Strycharska, the legendary former transport worker was remembered for her vital role (with three other women $)^{17}$ in transforming the August 1980 Gdańsk shipyard strike which was called off when workers' main initial demands (e.g. re-employment of the fired crane operator and activist, Anna Walentynowicz, and a pay rise) were satisfied into a "strike of solidarity" with other workers from smaller facilities as well as for her later commitment to "family orphanages," was awarded the title of "the Polish Woman of the Two Decades" of democracy. In another project, interviews with several key underground activists, such as Krzywonos-Strycharska, Ludwika Wujec and Olga Krzyżanowska, were published by Aleksandra Pawlicka in a collected volume documenting their resistance and reflections on the disappearance of women from the public life. In her testimony "How the women oppositionists disappeared from the poster of the democratic Poland," the veteran underground editor and activist, Ludwika Wujec, confirmed that women had not only been crucial in the underground publishing, especially during the martial law, that they saved the August 1980 strike, and that Grażyna Kuron insisted on adding the demand to free the political prisoners to the negotiated Gdańsk Agreements, but also reminded that only one woman, Grażyna Staniszewska, among 60 men represented them in the main Round Table Talks ${ }^{18}$. Occasionally, these interviews also powerfully evoked the repressions that affected women oppositionists during their anti-communist resistance such as imprisonment, internment, severe beatings sometimes causing miscarriage, as in the case of Henryka Krzywonos.

An auto/biographical narrative about both individual and social anti-communist resistance was another life writing genre employed in this second wave of more bitter remembering of the nearly 20 years of women's (in)visibility (except for short periods) in the mainstream public discourses. A rare instance of a single-author genre used to address this issue was Anka Kowalska's Folklor tamtych lat [Folklore of those Days] (2011), a posthumously published, hybrid fragmentary memoir combined with her published texts as well as internment "captivity narratives," censored letters and ironic poems defamiliarizing "grypsera" (the prison slang). The collected auto/biographical texts of this poet and writer capture her daily, active participation in the underground activism between 1976-1984 in Komitet

17 See also S. Penn, "Women at the Gates: Anna Walentynowicz and the August 1980 strikes", [in:] S. Penn, Solidarity's Secret..., pp. 29-65; and Ewa Ossowska, Henryka Krzywonos-Strycharska, who spoke also of late Alina Pieńkowska's role in the documentary Solidarność według kobiet. [Solidarity according to Women]. 2014. Directed/ Performed by Marta Dzido and co-directed by Piotr Śliwowski. 2014. Warszawa: Emotikonfilm. DVD.

18 L. Wujec, "Jak kobiety opozycji znikały z afisza demokratycznej Polski", [in:] A. Pawlicka, Czas na kobiety. Rozmowy z twórczyniami I Kongresu Kobiet [Time for Women: Interview with the creators of the First Congress of Women] Warszawa 2010, pp. 59-61. 
Obrony Robotników [Worker's Defence Committee] and in Solidarity resistance. In particular, she describes her witnessing and reporting of court hearings and the repressions of protesting workers. In addition, as an experienced editor, Kowalska suppresses her poetic idiom and devises a special, rigorously precise and concise style called "korkowiec" for underground reports to fit them on a small page of illegal "bibuła" publication ${ }^{19}$. This collection of her texts, partly published underground, also offers a survey of languages, used by the oppositionists, providing evidence of resistance to the official propaganda of the communist party, which dominated the mass media. For example, in one of her interviews she uses the convention of a captivity narrative to convey the shock of being arrested and interned in the morning after sixteen months of legal "Solidarity carnival," and hearing a bleak comment when she was trying to pack a few personal belongings: "Pani już nic nie będzie potrzebne" ["You won't need anything anymore, Ms.] ${ }^{20}$. Similarly to the tradition of slave narratives, Kowalska's personal account of her internment first in Gołdap Women's Camp, and report of being identified as the instigator of the Gołdap protests and moved to a stricter Darłówek internment camp for men and women, as well as her individual and collective portraits of other oppositionists, are legitimized by another leading underground woman editor of Tygodnik Mazowsze, Teresa Bogucka, in her introduction. Bogucka emphasizes that Kowalska's testimony about the long, complex, and peaceful negotiations and the use of various "non-violence" strategies of activism in KOR and Solidarność, are more valuable sources of Polish collective memory than current black-and-white reconstructions of the uprisings and battles glorifying the military conflict ${ }^{21}$.

An example of a rather uncommon genre of women's life writing underscoring the underground period is Danuta Wałęsa's autobiography, Marzenia i tajemnice [Dreams and Secrets] $(2011)^{22}$ recording her perspective as a witness-participant of her husband's activities, searches and arrests. Her very widely read and influential narrative about the social costs of civil resistance for which many women paid a rather disproportionate price inspired other creative projects ${ }^{23}$. It may also be viewed as a woman's counter-narrative to Andrzej Wajda's vision in his biopic, Watęsa. A Man of Hope (2013) and his earlier works.

However, many other extended stories about the Solidarity women were not published as self-narrated testimonies as if these women activists have been reluctant

19 "Anka... przysiadła gardło swojej pieśni i miast lirycznych wierszy pisała teksty prozy życia w PRL-u”, J. Kuroń in "Sam Pan Kuroń pisze o mnie", [in:] A. Kowalska, Folklor tamtych lat [Folklore of Those Days], Warszawa 2011, p. 247. "What is a pole? It's a tree edited by Tygodnik Mazowsze" an inside joke describes well style of underground editing according to Ludwika Wujec. See L. Wujec in M. Sutowski, Wujec. Zwiazki przyjacielskie, Warszawa 2013, p. 237.

20 E. Kowalska, op. cit., pp. 232-239.

21 T. Bogucka, Wstęp, [in:] A. Kowalska, op. cit., pp. 16-17.

22 D. Wałesa, Marzenia i tajemnice, oprac. P. Adamowicz, Kraków 2011.

23 Compare: K. Janda's theatre adaptation and performance in Danuta W., dir. J. Zaorski, Teatr Polonia, Warszawa 2012. 
to make themselves visible at the center of autobiographical narratives even if they have been generally viewed as crucial agents of resistance movement ${ }^{24}$.

Thus, one of the recently employed life narratives recounting the stories of Solidarity women's resistance is an individual or a collective biography focused primarily on women's nearly life-long activism and told by another, often younger, person. For example, Duża Solidarność, mała solidarność. Biografia Henryki Krzywonos [Big Solidarity, Small Solidarity. Biography of Henryka Krzywonos] $(2010)^{25}$ is narrated by a young journalist, film critic and activist, Agnieszka Wiśniewska, who foregrounds her protagonist's continuous involvement in various types of activism starting with August 1980 and her later volunteer work in devastated, post-communist, rural areas. However, Bożena Szczepuła's biography of Alina Pieńkowska, an important activist, a shipyard nurse, whose crucial role in informing Jacek Kuroń and the western press about the August massive protests and helping (with two other women) to transform the shipyard industrial action into a solidarity strike after the economic demands of a pay raise were satisfied by the communist government, and one of the three women signatories of Gdańsk Accords ${ }^{26}$, Alina Pieńkowska. Miłość w cieniu polityki, [Alina Pieńkowska. Love in the Shadow of Politics] (2013) ${ }^{27}$, as the subtitle suggests, is written in a more formulaic way conforming to the traditional feminine stereotype of a devoted lover. It highlights primarily Pieńkowska's underground relationship and terminal illness overshadowing her crucial achievements, especially during the Gdańsk August, as well as the limiting impact of her second husband's, Bogdan Borusewicz's political career, on her post-1989 public involvement. Regrettably, also Sławomir Cenckiewicz’s Anna Solidarność. Życie i działalność Anny Walentynowicz (1929-2010) (2010) [Anna Solidarity. Life and Activism of Anna Walentynowicz] uses Walentynowicz's biography as a pretext to demythologize Lech Wałęsa's role in the underground. Moreover, Cenckiewicz relies primarily and uncritically on the files of the secret police. Another view on the role of this iconic woman fighter and crane operator, whose firing started the Gdańsk shipyard's strike in 1980, is an underground biography Życie Anny Walentynowicz $(1985,2011)$ authored by Tomasz Jastrun. Finally, collected biographies of both male and female regional underground based on oral history interviews include the volume edited by the former woman oppositionist, Anka Grupińska, and a sociologist/historian, Joanna Wawrzyniak, Buntownicy: Polskie lata 70. i 80. [Rebels: Polish 70s and 80s] $(2011)^{28}$. In Skucha [Error] (2016), recent biographical narratives of post-1989 lives

24 Exceptions as mentioned ealier e.g.: A. Kowalska, Folklor tamtych lat [Folklore of Those Days], T. Bogucka, Przedmowa [Foreward], D. Wałęsa, Marzenia i tajemnice [Dreams and Secrets].

25 A. Wiśniewska, Duża Solidarność, mała solidarność. Biografia Henryki Krzywonos [Big Solidarity, Small Solidarity. Biography of Henryka Krzywonos], wstęp K. Szczuka, Warszawa 2010.

26 Penn, the two other women signatories of Gdańsk Accords were Anna Walentynowicz and Henryka Krzywonos; ibid., p. 60.

27 B. Szczepuła, Alina Pieńkowska. Miłość w cieniu polityki [Alina Pieńkowska. Love in the Shadow of Politics], Warszawa 2013.

28 A. Grupińska and J. Wawrzyniak, Buntownicy: Polskie lata 70. i 80., Warszawa 2011. 
of oppositionists, a former oppositionist and journalist, Jacek Hugo-Bader, examines a resistance group active in one Warsaw district (Wola). These intersectional biographies demonstrate how gender overlaps with other axes of identities such as class, ethnicity, illness/disability, region and sexual orientation (including a transsexual person, Ewa Hołuszko Hardy, who was born as Marek Cyryl Hołuszko) ${ }^{29}$ in post-resistance life.

Another significant genre of life writing about Polish anti-communist women dissidents uses the framework of extended (multimedia) interviews which dialogize these narratives. The modes of intersubjectivity and relationality seem vital to the process of recording their situated and engendered histories, since most of the published women's stories have been recovered in interaction with the interviewer, as in the earlier phase of "archive fever" oral history. As collaborative writing, they combine the individual with the collective perspectives creating multi-layered, double-voiced, often transgenerational discourses. An important example of a recent Polish eye-witness participant's account of events leading to Solidarity revolution and transformation is a book-length auto/biographical interview with one of the major, veteran women underground editors and activists of the resistance, Ludwika Wujec. Notably, it is conducted by a much younger political scientist, journalist and editor, Michał Sutowski and published by Krytyka Polityczna publishing house. Although its rather ambiguous, ungendered title ${ }^{30}$ Wujec. Zwiazki Przyjacielskie [Wujec: Friendly Relationships] (2013) may be misleading, since the same surname also refers to the husband of Ludwika Wujec, it is a valuable recent Polish eye-witness participant's account. In this recent life narrative, Ludwika Wujec presents the years of her underground activism rather modestly, as a series of communal projects involving networks of female and male friends in the pre-Internet era, instead of romanticized, heroic stories of larger-than-life male figures constantly involved in dramatic confrontations. Similar realistic evaluation is visible even in passages devoted to oppositionist friends enjoying the nearly cult status (especially among younger New Left people) such as Jacek Kuroń, who are occasionally evaluated negatively for their sporadic undemocratic decisions.

The most valuable aspect of this nearly life-long activist's auto/biography is how it contextualizes the multiple challenges of living in both legal (professional and familial) and "illegal" worlds. The questions posed by the interviewer foreground complex issues by focusing on Ludwika Wujec's social class, her Polish Jewish descent and her relatives' post-totalitarian left-wing activism. Moreover, Sutowski also explores the impact of ethnic conflicts and multiple dislocations which his interlocutor and her family experienced as a result of numerous anti-Semitic events. Signifi-

29 J. Hugo-Bader, Skucha [Error], Warszawa 2016. See also Encyklopedia Solidarności [Encyclopedia of Solidarity], Instytut Pamięci Narodowej, vol. I, II, Warszawa 2010, 2012.

30 Wujec is also the last name of Ludwika Wujec's husband, Henryk, who is more often present in the current media, hence the surname in the title may be misleading. The cover photograph of Ludwika Wujec gives a helpful hint. 
cantly, Wujec also explains her ambiguous positioning within post-Stalinist Polish "thaw" after October 1956, when her choice of physics as her major, in order to avoid communist indoctrination prevalent in the humanities, overlapped with her decision to join Związek Młodzieży Socjalistycznej [Polish Association of Socialist Youth] (together with numerous later oppositionists) in the hope of transforming it by the bottom-up activism and self-education projects. Particularly her dilemmas about her relatively late leaving of PZPR [Polska Zjednoczona Partia Robotnicza, Polish United Workers' Party] (1978), in the historical context of repressions against Polish and Polish Jewish dissidents under guise of anti-Semitic campaign culminating in March 1968 and her mother's concern that as a Jew she would be subjected to ruthless repressions, are rendered in their immense complexity. Yet, the period of her apparent complicity with the communist party, because of her vulnerable position as the member of the targeted ethnic minority and a mother of a young child, is undermined by her active involvement in the resistance, especially in KOR [Worker's Defense Committee] (since 1976) and as the key editor of the underground Robotnik [Worker] and Biuletyn Informacyjny, preparing for the integration of the working-class activists and public intellectuals in massive Solidarity movement of the 1980s. Her deep regret over being an inactive, yet formal, member of the communist party until 1978 severe beating of her husband, Henryk, by the young men from the communist student organization [SZSP $]^{31}$, despite her multiple activities in the anti-communist KOR, legal employment at school and the care for her young son, represent some of the ethical dilemmas the women oppositionists faced, which may be unfamiliar to younger people or passive witnesses. Her empathetic rendition of the first day of the martial law from her son's perspective is an example of the complications involved in combining motherhood with resistance. As a 10-year old boy, well-acquainted with conspiracy framework, on hearing that the martial law has been introduced, her son manages to direct his grandmother and they locate his mother working on free press in one of her friend's apartment. Then, as police appears, he pretends he is having a fever in the hope of preventing his mother's internment. Despite repressions, after her release from the internment camp, she continues to edit the underground weekly, Tygodnik Mazowsze (for five years). As a seasoned editor, she also cofounds several underground titles such as Niezależność [Independence] and becomes one of the key editors of the early Tygodnik Solidarność [Solidarity Weekly], but her position is soon filled by a minor male oppositionist. Such problems stemming from conservative gender arrangements are also portrayed vividly in a scene when Anna Walentynowicz arrives with Lech Wałęsa from Gdańsk for the oppositionists' meeting in Wujec's apartment in Warsaw and Wałęsa decides to unwind, while Walentynowicz immediately starts helping in the hosts' kitchen. Similarly, when Sutowski asks Wujec whether Shana Penn's publication is fair in highlighting women's role in Solidarity despite the mythical tale of its primarily male membership, Wujec confirms women's central role for example in transforming the

${ }^{31}$ L. Wujec, [in:] Wujec. Związki przyjacielskie. Rozmawia Michał Sutowski. Warszawa 2013. 
Gdańsk shipyard strike into the solidarity strike and the significance of their decision to stop the mass of workers leaving through the three gates. She also regrets that their role was misrepresented in Wajda's film Wałęsa, Man of Hope as an incident involving partly minor, anonymous female characters.

Sutowski's other extended interview, Graff. Jestem stad [I'm from here] (2014), records experiences of the younger generation of Polish anti-communist activists as remembered by Agnieszka Graff. In this intellectual auto/biography, Graff highlights her in participation between 1986 and 1988 in Warsaw resistance groups using surreal humor as well as the strategy of the tactical frivolity to resist the communist regime and explores the gendered aspects of resistance culture. As one of the founders of feminist Manifa movement, she underscores successful application of such performative strategies also to post-1989 street activism. Importantly, Sutowski also considers the issues of Graff's social class and ethnic background. Graff represents herself as the member of the second-generation of Holocaust survivors, and a well-travelled Pole returning from emigration because of her longing for her homeland. She also critically examines oppressive national and ethnic Polish stereotyping in the chapter titled significantly "Polak, Żyd, patriota" [A Pole, a Jew, a Patriot] and she self-identifies as both Polish and Jewish woman patriot despite the dominance of nationalist, patriarchal, exclusionary narratives. Such life narratives of women activists' interrogated by Sutowski provide a more intersectional analysis of gender, ethnicity, class and age in constructing multiple, layered Polish identities.

The recent new wave of interest in the individual and collective public self-definition of (former) women activists has re-opened a debate not only on the long-delayed engendering the mainstream history of 1980s Solidarity and anti-communist resistance especially in a more accessible form of a documentary film, urban projects, internet-circulated archive or artwork for the younger, media-literate audience, but also provided a penetrating critique of women's complicity in the transformation's errors and the symbolic removal of women from the mainstream media.

\section{Interacting with Solidarity women — The new media/ urban projects, visual arts and film}

One of the most outstanding features of this second wave of women's life narratives about the anti-communist underground is the active involvement of younger, media-literate generation of women and men. For example, a herstory (as contrasted with history) project, Stocznia jest kobietal [Shipyard is a Woman] has been developed by Metropolitank $a^{32}$, an interdisciplinary group of young, local women collecting oral interviews with Solidarity women activists, workers and artists asso-

32 Compare: E. Klimek-Dominiak, “Jak zwiedza feminist(k)a?”, Zadra, pismo feministyczne 2015, no. 1-2 (62-63), pp. 23-25. 
ciated with Gdańsk Shipyard. They conduct special walks in the Gdańsk Shipyard, in which they problematize women's ,invisible" participation in opposition before ' 89 and reclaim this post-industrial space for them. Their highly interactive and transgenerational projects pay tribute to women who remained anonymous for too long:

There were over 5000 women working in Gdańsk Shipyard on different positions such as crane drivers or welders. Despite that, their involvement in the development and prosperity of this place is still underestimated. It should be remembered that they had to combine full-time physical job with household duties. What is more, they had very few promotion prospects despite superficial equality of rights offered by communism. Also, their jobs caused health problems such as asbestosis, allergy or miscarriage. Even worse, women working in the Shipyard were sexually abused, which is proved by a case of a child conceived as a result of the rape $\mathrm{e}^{33}$.

Importantly, a recent, award-winning documentary, Solidarity according to Women (2014) narrated by a young writer/co-director, Marta Dzido, includes oral interviews featuring Solidarity women reflecting on their position in Solidarity resistance and after 1989 marking a change in the self-definitions of several central women activists. This perspective of a young woman narrator (born in 1981) and positioned as a "symbolic daughter of Solidarity," is highlighted by the contemporary remake of the cult Solidarity ballad titled "Piosenka dla córki" [A Song for a Daughter], which is performed in a strong, dynamic voice by a young woman singer, Maria Holka. In addition to a powerful effect of visualizing the crucial women's contributions discovered earlier in the "archive fever" phase, and including a contemporary portrayal of the iconic shipyards cranes, Marta Dzido and Piotr Śliwowski focus their attention on exploring the critique of women's treatment both in the underground and during transformation. The polyphonic stories of women, who after 1989 have continued their activism and those who have returned to their traditional pre-underground roles, emerge in response to questions posed by a young woman director. In addition to age difference, the film editing also underscores intersections of gender and class as one of the close-ups on the oppositionist's bookshelf, shows David Ost's critical study, Defeat of Solidarity. Anger and Politics in Postcommunist Europe (2005). Similarly, Helena Łuczywo, the editor-in-chief of Tygodnik Mazowsze, cofounder of Gazeta Wyborcza, admits her regret about the highest costs of economic transformation paid by the former state-owned factory workers and members of Solidarity, but she also notes that no one has been able to prevent it. ${ }^{34}$ Moreover, many underground women activists have also suffered negative effects of the economic "shock therapy." In particular, Ewa Ossowska, one of the women crucial in transforming Gdańsk August 1980 strike into

33 A. Miller, "Stocznia jest kobietą. Opowieści kobiet ze Stoczni Gdańskiej." Stowarzyszenie Arteria, transl. M. Ossowska, 2012, http://metropolitanka.ikm.gda.pl/dzialania/zwiedzanie/zwiedzanie-stoczni/gdansk-shipyard-from-womens-perspective- (access: 14.08.2016).

34 Compare: E. Klimek-Dominiak, "Właściwie to dużo zawdzięczamy feministkom," Codziennik feministyczny 27.02.2015, http://codziennikfeministyczny.pl/wlasciwie-duzo-zawdzieczamy-feminist/(access: 8.03.2016). 
a solidarity protest, as a single mother unable to find a job, she felt she had to become an economic emigrant after 1989 to be able to support her children.

Drawing on Foucauldian concept of power inscribing its resistances and seeking to contain them as well as Jenny Sharpe's theorization of colonial and postcolonial resistance in white settler-colonial literary writing in English, Stephen Lemon underscores that "resistance itself is never... purely resistance, never simply there in the text or the interpretive community, but is always necessarily complicit in the apparatus it seeks to transgress." 35 Similarly, in Solidarity according to Women Dzido shows one of the leading underground journalists, Janina Jankowska being interviewed about her choice not to include any opposition women in her interviews with the founders of Solidarity at first resisting the question, and eventually experiencing an illumination about her own complicity in disregarding women's testimonies ${ }^{36}$. In a coda to this scene, Jankowska, portrayed in the process of soul-searching, starts naming the women of the anti-communist resistance, who could have been given a voice, but also tries to defend her decision to disregard some of them in her official representation of underground since they were "represented" by their husbands. Faced with Dzido's strong counterarguments about her role in omitting the narratives of the equally important women leaders of Solidarity, Jankowska eventually remarks pensively: "Actually, we owe a lot to feminists" 37 [who recovered their stories].

In another transgenerational, multimedia life narrative about women's participation in resistance including Solidarity, Zuzanna Janin combines the famous symbolic visual representations of a male and a female into two Solidarity oppositionists in her poster "After Sarnecki and Ivecović (2014). This image of the couple is accompanied by her personal narrative "Solidarność. List do Mamy" [Solidarity. A Letter to My Mum $]^{38}$ paying tribute to women in her family active in various resistance movements, concluding with her late mother, an accomplished painter, involved in underground activism in the 1980s and Solidarność Artystów [Solidarity of Artists]. Framing her visual/verbal project commemorating the $25^{\text {th }}$ anniversary of the first partially free elections with this modified iconic poster, Janin underscores the importance of gender in the visual representation of resistance.

35 S. Slemon, "Unsettling the Empire: Resistance theory for the Second World", [in:] B. Ashcroft, G. Griffiths, and H. Tiffin (eds.), The Post-colonial Studies Reader, London 1995, pp. 104-110.

36 Compare: J. Jankowska, Portrety niedokończone: Rozmowy z twórcami „Solidarności” 19801981 [Unfinished Portraits: Conversations with the Founders of Solidarity], wstęp, kalendarium i przypisy A. Friszke, Stowarzyszenie Archiwum „Solidarności”, Warszawa 2004.

37 Solidarność według kobiet [Solidarity according to Women], dir. M. Dzido, P. Śliwowski, Warszawa 2014. Compare: E. Klimek-Dominiak, "Właściwie to dużo zawdzięczamy feministkom - Solidarnośc według kobiet”, Warszawa 2015, http://codziennikfeministyczny.pl/wlasciwie-duzozawdzieczamy-feminist/ (access: 8.03.2016).

38 Z. Janin, "Solidarność. List do Mamy", Na temat 8.03.2014, http://zuzannajanin.natemat. pl/104919,solidarnosc-list-do-mamy- (access: 4.06.2016). 


\section{(In)visibility of Solidarity women in Central and Eastern European gender history, postcolonial and life writing studies}

As Hana Cervinkova, Dorota Kołodziejczyk and Agnieszka Matusiak point out, the languages, genres and rhetoric of anti-communist resistance are rarely addressed in postcolonial studies as even "Barbara Harlow's seminal study Resistance Literature (1987), focusing on Third World revolutionary writing, lacks symptomatically, even a scant reference to the then teeming revolutionary and resistance literatures in Central and Eastern Europe" (2015). ${ }^{39}$ Similarly, in a later collection of essays on diverse life writing on decolonization in the global perspective, De/Colonizing the Subject: The Politics of Gender in Women's Autobiography (1992), its Anglo-American editors, Sidonie Smith and Julia Watson, do not consider any East or Central European post-totalitarian autobiographical practices and Europe is usually conflated with Western Europe in their introductory essay. One of its contributors, Caren Kaplan referring the Enlightenment universalist definition of autobiographical individual subject and Derrida's law of the genre in her influential essay "Resisting Autobiography: Out-Law Genres and Transnational Feminist Subjects" poses interesting questions: "If Western autobiography criticism is itself a form of colonial discourse, does Western feminist autobiography criticism continue postcolonial form of domination? Are there reading and writing strategies that historicize and deconstruct mythologies of nationalism and individualism? What kind of postcolonial writing and reading strategies intersect with feminist concerns to create transnational feminist subjects?" 40 . However, in her interdisciplinary discussion of "resistance literature" such as women's prison memoirs, testimonial narratives, ethnographic writing, biomythography and "regulative psychobiographies" Kaplan does not mention any genres capturing women's anti-communist resistance ${ }^{41}$. Similarly, in more recent Postcolonial Theory and Autobiography (2008) David Huddart emphasizes the importance of both feminism and Donna Haraway's concept of locatable "situated knowledge" for postcolonial autobiography, but he does not make any non-Western European post-totalitarian feminist standpoints visible in his study.

Although the Dutch historian, Marijke Huisman, invokes in her "Introduction" to Life Writing Matters in Europe (2012) cross-cultural deconstruction of Eurocentric and patriarchal conceptualization of autobiography and highlights the end of the Cold War as a decisive moment for the increase of auto/biographies by people from

39 H. Cervinkova, D. Kołodziejczyk, A. Matusiak, “The tropics of resistance: Languages, genres, rhetoric", Call for Papers. Research Center for Postcolonial and Post-totalitarian Studies at the Faculty of Philology, Wroclaw University. May 27-28 2015 http://www.wfil.uni.wroc.pl/archiwum- (access: 3.05.2015).

40 C. Kaplan, "Resisting autobiography: Out-law genres and transnational feminist subjects", [in:] S. Smith, J. Watson (eds.), De/Colonizing the Subject: The Politics of Gender in Women's Autobiography, Minneapolis 1992, p. 116.

41 Ibid., p. 132. 
Eastern European countries, "where life writing is instrumental in making visible stories and people that were not heard or listened to before the rise to independence," only 3 of 19 contributions to the volume concern personal narratives about the transformations in the post-communist bloc ${ }^{42}$. Significantly, none of the three articles by Martins Kaprans, Leena Kurvet-Käosaar and Ioana Luca on Latvian, Estonian and Romanian personal narratives explores the impact of (post)communist resistance on cultural changes in gender constructions in the Central or Eastern Europe and so women active in this defining moment remain largely (in)visible.

Even though Maria Bucur claims that "most historians continue to ignore the fundamental gendered aspects of the Polish mass movement Solidarity gender history", and she does mention briefly Penn's 2005 and Kenney's 1999 publications, she underlines that their findings have not yet been thoroughly integrated into the history of Solidarity and calls for a greater recognition of gender among the Eastern European historians ${ }^{43}$. A similar, more recent publication of Eliza Kania, "Polska zdekolonizowana? Pamięć o kobietach i jej wymiary" 44 , also notes briefly oral history on Solidarity women and suggests the need to expand gender analysis in order to decolonize women's memory in the collective consciousness. Also a philosopher Ewa Majewska is working on the article "Solidarnosc' reloaded. Resistance of the weak and the non-heroic" exploring the women activists' positioning within the postcolonial framework ${ }^{45}$

As the largest civic resistance movements in Europe during World War $\mathrm{II}^{46}$ and Solidarity underground seem to be Polish "trademarks," it has become increasingly difficult to ignore the impact of gender on Polish post-totalitarian narratives of collective identity. The American and Polish social historians, journalists and artists use multimedia, interdisciplinary methodologies and hybrid dialogical genres to remember women who were active in the Polish anti-communist underground of the 1980s but have remained largely (in)visible in the mainstream representations of Polish history. These oral history projects and multimedia life writing tend to destabilize the popular product of Polish oppositional myth - making the enduring

42 M. Huisman, "Introduction", [in:] M. Huisman, A. Ribberink, M. Soeting (eds.), Life Writing Matters in Europe, Heidelberg 2012, pp. 9-17, here: p. 12.

${ }^{43}$ M. Bucur, "An archipelago of stories: Gender history in Eastern Europe", The American Historical Review 2008, 113, no. 5, pp. 1375-2389, here: p. 1387.

44 E. Kania, "Polska zdekolonizowana? Pamięć o kobietach i jej wymiary", Refleksje 2011, no. 4, https://issuu.com/refleksje/docs/refleksje-nr4. (access: 5.05.2016).

45 E. Majewska, "'Solidarnosc' reloaded. Resistance of the weak and the non-heroic", Draft. Academia.Berlin, 2017 (access: 5.12.2016), https://www.academia.edu/25589274/Subaltern_counter_ publics._Draft. (access 5.12.2016).

${ }^{46}$ Engendering of Solidarity also paved way for introducing gender analysis of Polish historical e.g. the 1944 Warsaw Uprising in W. Grzebalska, Płeć Powstania Warszawskiego [Gender of the Warsaw Uprising], Warszawa 2014. Compare: I. Mrzygłód, W. Grzebalska, "Płeć powstania warszawskiego" recenzja, Histmag.org 2014, http://histmag.org/Weronika-Grzebalska-Plec-powstania-warszawskiegorecenzja-9813 (access: 5.05.2016). 
image of a strong, rebellious, usually bearded, male individual. In contrast, they often emphasize the communal as well as gendered features of this underground social movement. In the process of recording their life stories closely connected to underground anti-communist activism, they present a more complex view of underground Solidarity and Polish society. They have also contributed to a more intersectional examination of gender, ethnicity, class and age, and consequently have highlighted discourses reconsidering Polish national, ethnic and civil identities which may be helpful in resisting the nationalist appropriation of the oppositional discourse ${ }^{47}$. It has become increasingly difficult to ignore the impact of gender studies, oral history and life writing on post-totalitarian narratives of collective as well as individual identities in Poland and other post-communist countries.

Polish women's auto/biographical resistance narratives have helped to reclaim and engender the history of underground Solidarity and have contributed to the contemporary process of redefining Polish national and civil narratives of identity. This process has been polyphonic, fragmentary and full of relapses into traditional ways of narrating collective history and individual lives. Hence it requires a further revision of the master narrative of Solidarity's male independent leaders and many other male-gendered chapters in Polish political, social and personal histories as well as more comparative post-totalitarian studies of the role of gender in both (oral) history and multimedia life writing. Further research might also consider inter-class and transnational constructions of oppositional masculinity, their representations of the costs of resistance, their strategies of self-elevation and their ways of erasing women's major contributions in oral history and life writing about 1980s and more recent oppositional movements. Additionally, since Dzido has continued her three-year research focused on identifying anonymous women in the archives of the underground for her documentary film, her latest book, Kobiety Solidarności [Solidarity Women] (2016), may prove an interesting material to examine women's anti-communist activism in greater detail and in comparison to women's and men's resistance in other post-Soviet bloc countries ${ }^{48}$. Notably, outpouring of life writing about Polish dissident women shows no signs of abating. Similarly, the debate about the younger women activists' right to use Solidarity's visual representation in

47 Compare various right-wing representations of Polish women's World War II resistance e.g. S. Nowak, Dziewczyny Wyklęte [Disavowed Girls], Warszawa 2016; “Morowe Panny”, [in:] Powstanie '44 w komiksie. Antologia prac konkursowych, Warszawa 2010; Muzeum Powstania Warszawskiego (eds.) [The Museum of the Warsaw Uprising], Anthology of the Comics Competition, Warszawa 2010 with gendered oral history Powstanie $w$ bluzce $w$ kwiatki. Życie codzienne kobiet $w$ czasie Powstania Warszawskiego [Uprising in the Flowery Shirt: Daily Life of Women of the Warsaw Uprising]; Fundacja Feminoteka (eds.), Wirtualne Muzeum Historii Kobiet [Virtual Museum of Women's History], YouTube, Warszawa 15.10.2009, https://www.youtube.com/watch?v=orTZaPJHaoA (access: 1.08.2016).

48 M. Dzido, Kobiety Solidarności, Warszawa 2016. 
their recent black protests ${ }^{49}$ may serve as a visible sign of a revival of transgenerational solidarity despite the anti-gender backlash.

\section{Bibliography}

Bogucka, T. 2011. "Przedmowa" [Foreword]. In A. Kowalska, Folklor tamtych lat. Warszawa: Więź, pp. 5-17.

Bucur, M. 2008. "An archipelago of stories: Gender history in Eastern Europe." The American Historical Review 113. no. 5. 1375-2389.

Cervinkova, H., Kołodziejczyk, D., Matusiak, A. 2015. “The tropics of resistance: Languages, genres, rhetoric”. Call for Papers. Research Center for Postcolonial and Post-totalitarian Studies at the Faculty of Philology, Wroclaw University. http://wfil.uni.wroc.pl/research-center-for-postcolonialand-posttotalitarian-studies/archive/?lang=en.

Danuta W. 2012. Adaptation of D. Wałęsa. Marzenia i tajemnice. Oprac. P. Adamowicz. Performance by K. Janda. Directed by J. Zaorski. Warszawa: Teatr Polonia.

Dzido, M. 2016. Kobiety Solidarności. Warszawa: Świat Książki.

Encyklopedia Solidarności. 2010-2016. http://www.encysol.pl/wiki/SG_Redakcja.

Europejskie Centrum Solidarności (eds.). 2015. European Solidarity Centre. Permanent Exhibition. Anthology. Gdańsk: ECS.

Feffer, J. 2015. "Building the woman's movement. Interview with Małgorzata Tarasiewicz." Huffington Post. The World Post. April 10. http://www.huffingtonpost.com/john-feffer/building-the-womens-movem_b_7039784.html.

Feffer, J. 2015. "Solidarity underground. Interview with Ewa Kulik." Huffington Post. The World Post. April 7. http://www.huffingtonpost.com/john-feffer/solidarity-underground_b_7019818.html.

Graff, A. 1999. "Patriarchat po Seksmisji”. Gazeta Wyborcza. Świąteczna June 19-20 [after:] S. Penn. 2005. Solidarity's Secret. The Women Who Defeated Communism in Poland. Ann Arbor: University of Michigan Press. 20-23.

Graff, A. 2001. Świat bez kobiet. Płeć w polskim życiu publicznym. Warszawa: WAB.

Graff, A. 2005. "Dziewczyna opozycjonisty." In S. Walczewska (eds.). Feministki własnym głosem o sobie. Kraków: eFKa. 80-108.

Graff, A. 2014. Graff. Jestem stąd. Rozmawia Michał Sutowski. Warszawa: Wydawnictwo Krytyki Politycznej.

Grupińska, A., Wawrzyniak, J. 2011. Buntownicy. Polskie lata 70. i 80. Warszawa: Świat Książki.

Grzebalska, W. 2014. Płeć Powstania Warszawskiego. Warszawa: Instytut Badań Literackich PAN, Narodowe Centrum Kultury.

Hugo-Bader, J. 2016. Skucha. Wołowiec: Czarne.

Huisman, M. 2012. “Introduction”. In M. Huisman, A. Ribberink, M. Soeting (eds.). Life Writing Matters in Europe. Heidelberg: Universitätsverlag. 9-17.

Janda K., 2012. Theatre adaptation and performance of Danuta W., Dir. J. Zaorski. Teatr Polonia, Warszawa.

Janin, Z. 2016. “Solidarność. List do Mamy.” Na temat. March 8. http://zuzannajanin.natemat.pl/104919,solidarnosc-list-do-mamy.

49 „Autor znaku 'Solidarności' staje w obronie kobiet z Czarnego Protestu. Nie chce ich ścigania” [http://wiadomosci.gazeta.pl/wiadomosci/7,114883,20834134, autor-znaku-solidarnosci-staje-wobronie-kobiet-z-czarnego.html-- (access: 21.10.2016). 
Janion, M. 1999. “For Your Freedom and Ours.” (Gazeta Wyborcza July 4, 1999) [after:] S. Penn. 2005. Solidarity's Secret. The Women Who Defeated Communism in Poland. Ann Arbor: University of Michigan Press. 333-334.

Jankowska, J. 2004. Portrety niedokończone: Rozmowy z twórcami "Solidarności” 1980-1981. Wstęp, kalendarium i przypisy by A. Friszke. Warszawa: Biblioteka Więzi.

Jarska, N., Olaszek., J. (eds.). 2014. Płeć buntu. Kobiety w oporze społecznym i opozycji w Polsce w latach 1944-1989 na tle porównawczym. Warszawa: Instytut Pamięci Narodowej. 355-369.

Kania, E. 2011. “Polska zdekolonizowana? Pamięć o kobietach i jej wymiary"” Refleksje 4. https://issuu. com/refleksje/docs/refleksje-nr4.

Kaplan, C. 1992. "Resisting autobiography: Out-law genres and transnational feminist subjects." [in:] S. Smith, J. Watson (eds.). De/Colonizing the Subject: The Politics of Gender in Women's Autobiography. Minneapolis: University of Minnesota Press. 115-138.

Klimek-Dominiak, E. 2015. "Właściwie to dużo zawdzięczamy feministkom — Solidarność według kobiet.” Codziennik Feministyczny. http://codziennikfeministyczny.pl/wlasciwie-duzo-zawdzieczamy-feminist/.

Klimek-Dominiak, E. 2015. "Jak zwiedza feminist(k)a?” Zadra. Pismo feministyczne 1-2 (62-63). 23-25.

Klimek-Dominiak, E. 2015. "80 milionów i 80 tysięcy”. Zadra. Pismo feministyczne 2-3 (64-65). 66-67.

Klimek-Dominiak, E. 2016. "Resisting (in)visible women of Solidarity: Gender in American and Polish oral history, life writing, visual arts and film. Part I”. Miscellanea Posttotalitariana Wratislaviensia. Special Issue. 1. DOI: 10.19195/2353-8546.1(5).9. 103-121.

“Kobiety i Solidarność. Skąd przychodzimy, dokąd zmierzamy?” 2014. Relacja z konferencji. Heinrich Böll Stiftung. Warszawa. June 2. https://pl.boell.org/pl/2014/05/28/kobiety-i-solidarnosc-skadprzychodzimy-dokad-zmierzamy.

Kowalska, A. 2011. Folklor tamtych lat. Warszawa: Więź.

Krzywonos, H. 2010. "Jak legenda Solidarności uczyła się kochać." [in:] A. Pawlicka. Czas na kobiety. Rozmowy z twórczyniami I Kongresu. Warszawa: Aletheia. 57-59.

Limanowska, B. 2005. “Ucieczka do wolności." [in:] S. Walczewska (eds.). Feministki własnym głosem o sobie. Kraków: eFKa. 109-120.

lulu. 2016. "Autor znaku 'Solidarności' staje w obronie kobiet z Czarnego Protestu. Nie chce ich Ścigania." 13.10. http://wiadomosci.gazeta.pl/wiadomosci/7,114883,20834134,autor-znaku-solidarnosci-staje-w-obronie-kobiet-z-czarnego.html.

Łątkowska, M. (eds.). 2010. Encyklopedia “Solidarności”. Opozycja w PRL 1976-1989. vol. 1. Warszawa: Oficyna Wydawnicza Volumen-Katowice: Stowarzyszenie Pokolenie.

Majewska, E. 2016. “'Solidarnosc' reloaded. Resistance of the weak and the non-heroic." Subaltern counter publics. Draft. Academia. ICI Berlin. https://www.academia.edu/25589274/Subaltern_counter_publics._Draft.

Miller, A. 2012. "Stocznia jest kobietą. Opowieści kobiet ze Stoczni Gdańskiej.” Trans. by M. Ossowska. Gdańsk: Stowarzyszenie Arteria. http://metropolitanka.ikm.gda.pl/dzialania/zwiedzanie/zwiedzanie-stoczni/gdansk-shipyard-from-womens-perspective-/.

“Morowe panny”. 2011. In Powstanie'44 w komiksie. Antologia prac konkursowych 2010. Warszawa: Egmont.

Mrzygłód, I. 2014. Review of Płeć powstania warszawskiego by W. Grzebalska. Histmag.org. http://histmag.org/Weronika-Grzebalska-Plec-powstania-warszawskiego-recenzja-9813.

Nowak, S. 2015. Dziewczyny wyklęte. Warszawa: Fronda.

Ost, D. 2005. Defeat of Solidarity. Anger and Politics in Postcommunist Europe. Ithaca: Cornell University Press.

Penn, S. 2014. "Analiza porównawcza działalności kobiet w czechosłowackich i polskich ruchach opozycji antykomunistycznej w latach 1968-1989.” [in:] N. Jarska, J. Olaszek. Płeć buntu. Kobiety w oporze społecznym i opozycji w Polsce w latach 1944-1989 na tle porównawczym. Warszawa: Instytut Pamięci Narodowej. 355-369.

Penn, S. 2003. Podziemie kobiet. Warszawa: Rosner i Wspólnicy. 
Penn, S. 2015. Sekret “Solidarności." Trans. by M. Antosiewicz. Warszawa: WAB.

Penn, S. 2005. Solidarity's Secret. The Women Who Defeated Communism in Poland. Ann Arbor: University of Michigan Press.

Penn, S. 2009. "Writing themselves into history: Two feminists recall their political development in the People’s Republic of Poland." [in:] S. Penn, J. Massino (eds.). Gender Politics and Everyday Life in State Socialist Eastern and Central Europe. New York: Palgrave Mcmilllan. 201-219.

Powstanie w bluzce w kwiatki. Życie codzienne kobiet w czasie Powstania Warszawskiego. 2009. Wirtualne Muzeum Historii Kobiet. YouTube. Warszawa: Fundacja Feminoteka. https://www.youtube. com/watch?v=orTZaPJHaoA.

Slemon, S. 1995. "Unsettling the Empire: Resistance theory for the Second World." [in:] B. Ashcroft, G. Griffiths, and H. Tiffin (eds.). The Post-colonial Studies Reader. London: Routledge. 104-110.

Solidarność według kobiet. [Solidarity according to Women]. 2014. Directed/Performed by M. Dzido and co-directed by P. Śliwowski. Warszawa: Emotikonfilm. DVD.

Szczepuła, B. 2013. Alina Pieńkowska. Miłość w cieniu polityki. Warszawa: WAB.

Szczęsna, J. 1999. “Ladies, Knights, and Fireperson.” (Gazeta Wyborcza June 27. 22-23.) [after:] S. Penn. 2005. Solidarity's Secret: Women Who Defeated Communism in Poland. Ann Arbor: University of Michigan Press. 330-333.

Szczuka, K. "Wstęp ideologiczny i trochę sentymentalny." Introduction to Duża Solidarność, mała solidarność. Biografia Henryki Krzywonos. Warszawa: Wydawnictwo Krytyki Politycznej. 5-8.

Tarasiewicz, M. 1993. "Kobiety i Związek Zawodowy 'Solidarność”’ Pełnym Głosem. Lato 1. 30-33.

Tarasiewicz, M. 2005. “Solidarność kobiet.” [in:] S. Walczewska (eds.). Feministki własnym głosem o sobie. Kraków: eFKa. 21-33.

Umińska, B. 2005. "Stemplowanie tożsamości." [in:] S. Walczewska (eds.). Feministki własnym głosem o sobie. Kraków: eFKa. 109-120.

Waligóra, G. (eds.). 2012. Encyklopedia “Solidarności”. Opozycja w PRL 1976-1989. vol. 2. Warszawa: Oficyna Wydawnicza Volumen-Katowice: Stowarzyszenie Pokolenie.

Wałęsa. Człowiek z nadziei. 2012. Directed by A. Wajda. Warszawa: Akson Studio. DVD.

Walczewska. S. 1992. “O potrzebie historii kobiecej.” [in:] S. Walczewska (ed.). Głos maja kobiety. Teksty feministyczne. Kraków: eFKa. 57-63.

Wałęsa, D. 2011. Marzenia i tajemnice. Oprac. P. Adamowicz. Kraków: Wydawnictwo Literackie.

Watson, P. 1993. “Eastern Europe’s Silent Revolution: Gender." Sociology 3, 27. 471-487.

Wiśniewska, A. 2010. Duża Solidarność, mała solidarność. Biografia Henryki Krzywonos. Warszawa: Wydawnictwo Krytyki Politycznej.

Wujec, L. 2010. “Jak kobiety opozycji znikały z afisza demokratycznej Polski.” [in:] A. Pawlicka. Czas na kobiety. Rozmowy z twórczyniami I Kongresu. Warszawa: Aletheia. 59-61.

Wujec, L. 2013. Wujec. Związki przyjacielskie. Rozmawia Michał Sutowski. Warszawa: Wydawnictwo Krytyki Politycznej.

Przyjęto do druku/Accepted for publication: 4.10 .2016

Miscellanea Posttotalitariana Wratislaviensia 6/2017

(C) for this edition by CNS 